\title{
Organizational Problems of Machine-Building Enterprises in the Context of Small-Scale Production
}

\author{
Lyudmila Tipner ${ }^{1}$, Yuliya Markova ${ }^{1,{ }^{*}}$, and Nikita Vasiliev $^{1}$ \\ ${ }^{1}$ Institute of New Materials and Technologies, Ural Federal University named after the first President \\ of Russia B.N. Yeltsin, 620002, 19 Mira street, Ekaterinburg, Russia
}

\begin{abstract}
The need to increase labour productivity and improve the competitiveness of engineering products, as well as to increase high-tech exports, are urgent tasks for the development of industry in the Russian Federation. The creation of competitive products implies flexibility in the approach to the consumer, which leads to an increase in the share of enterprises operating in conditions of small-scale production. The purpose of this study is to assess the reserves of productivity growth at machinebuilding enterprises of small-scale and unit-type production in the Ural region. Research has shown that organizational factors, such as the automation of production preparation processes, the use of photo-timing studies in the conditions of small-scale production, have a significant impact on labour productivity. In this case, the solution of organizational problems helps to create informational database for introduction at the enterprises of mechanical engineering complex life cycle management of products (the PLM).
\end{abstract}

\section{Introduction}

Machine-building engineering is an industry that provides a high potential for the country's industry, employment of a large circle of specialists and a decent level of their income. At the same time, according to Rosstat estimates, changes are taking place in the structure of industrial production in Russia that do not reduce the economy's dependence on raw materials. A Proportion of mining has increased from $34.1 \%$ in 2010 to $38.9 \%$ in 2018 , while the share of the manufacturing sector declined from $53.2 \%$ to $50.7 \%$. The share of production of petroleum products increased from 17 to $23 \%$, while the share of metallurgical production and machine building declined. [2]

The increase in the export of industrial products, a significant share of which is allocated to mechanical engineering products, is the main direction of the Consolidated Strategy and Development of the Manufacturing Industry of the Russian Federation [1] until 2024 and for the period until 2035. The strategy defines the priority directions for the development of sub-sectors of mechanical engineering: aviation, shipbuilding, automotive and electronic industries, transport and agricultural, heavy and power engineering. The

\footnotetext{
*Corresponding author: yunimark@mail.ru
} 
achievement of the key goals of the strategy, despite the differences in their quantitative assessment, presupposes an increase in the competitiveness of engineering products.

Increasing the competitiveness of products involves the release of high-tech products at an acceptable price level. Among the factors that reduce the competitiveness of products domestically of mechanical engineering are high cost of production, low labour productivity, insufficient use of innovative technologies and organizational decisions.

Achieving success in solving the problems of increasing competitiveness is complicated by the fact that in modern conditions flexibility in the approach to the consumer is necessary. The production of a single and small-scale type is more adapted to fluctuations in demand. According to experts, at present the share of such enterprises in mechanical engineering is $75-85 \%$. [3]

A substantial part of machine-building enterprises produces defense products. As a rule, this is a production of a single or small-scale nature, which requires taking into account special conditions, both in the design and production.

A promising direction of high-tech production development and increasing the share of exports in the engineering industry is to diversify. As shown by an earlier study [4], problems in the implementation of diversification arise at all stages of the product life cycle. On the stage of production is issues related to shortcomings in the organization of production, the lack of scientific and production cooperation, dependence on imported component part, etc. [4]

\section{Materials and Methods}

The purpose of this study is to identify the problems and factors affecting the labour productivity of machine-building enterprises, in the conditions of small-scale and unit-type production. The above arguments suggest that these problems are relevant for most machine-building enterprises.

Studies conducted on JSC "OKB" Innovator", JSC "UZGA" conditions of production on which, for the most part, have signs of small-batch and unit type, allowed us to formulate the hypothesis that organizational factors have a significant impact on labour productivity.

\subsection{The business process of incoming inspection of products in the mechanical assembly shop research}

The subject of research at JSC "OKB "Novator" was the business process of incoming inspection of products in the mechanical assembly shop, the average duration of which takes more than a month. The main problems identified during the study:

- great length clearance of documents in the absence of items in a list of DSE (parts and assembly units);

-irrationally structured communication process between departments and outside organizations;

- long process of consideration and approval of documentation;

-irrationally built route of incoming control operations.

Ways to solve these problems are primarily related to automation, the creation of systems for production preparation (CAD, CAM, CAE, PDM systems), production management systems (MES and ERP systems) and EAM resource management systems.

Possibilities for reducing the duration of processes based on optimization of interaction, the use of electronic document management, and an increase in the responsibility of performers are presented in Table 1. 
Table 1. Duration of process a of incoming inspection of parts before and after process improvement.

\begin{tabular}{|c|c|c|c|c|}
\hline Process & $\begin{array}{l}\text { Duration, } \\
\text { min. }\end{array}$ & $\begin{array}{l}\text { Share of the } \\
\text { total process } \\
\text { duration, } \%\end{array}$ & $\begin{array}{l}\text { Duration, } \\
\text { min. }\end{array}$ & $\begin{array}{l}\text { Share of the } \\
\text { total process } \\
\text { duration, } \%\end{array}$ \\
\hline $\begin{array}{l}\text { The study of the } \\
\text { requirements first and check stock } \\
\text { availability }\end{array}$ & 60 & $\mathbf{0 , 2 0}$ & 40 & $\mathbf{0 . 3 0}$ \\
\hline $\begin{array}{l}\text { Analysis and registration of a } \\
\text { passport for entrance control }\end{array}$ & 9093 & 22.2 & 2900 & 18.5 \\
\hline $\begin{array}{l}\text { Waiting for volumes of incoming } \\
\text { inspection }\end{array}$ & 5760 & 14.06 & - & - \\
\hline $\begin{array}{l}\text { Ordering and waiting for the } \\
\text { registration of passports in the archive }\end{array}$ & 2880 & 7.03 & 2880 & 18.43 \\
\hline Passage of VHK & 11030 & 26.9 & 4838 & 31.0 \\
\hline $\begin{array}{c}\text { Checking the accompanying } \\
\text { documentation and the appearance of } \\
\text { the Quality Control Department and } \\
\text { PZ }\end{array}$ & 480 & 1.17 & 12 & 0.13 \\
\hline Waiting for QC department check & 5760 & 14.06 & 120 & 0.77 \\
\hline Quality control department check & 2880 & 7.03 & 2880 & 18.43 \\
\hline $\begin{array}{l}\text { Closing the passport for incoming } \\
\text { control and revision of the part }\end{array}$ & 20785 & 50.7 & 7850 & 50.2 \\
\hline $\begin{array}{l}\text { Waiting for shipment of a part for } \\
\text { revision }\end{array}$ & 1440 & 3.52 & 1440 & 9.21 \\
\hline Refinement & 17280 & 42,2 & 4320 & 27.64 \\
\hline Waiting for re-examination & 1440 & 3.52 & 120 & 0.77 \\
\hline TOTAL & 40968 & 100 & 15628 & 100 \\
\hline
\end{tabular}

For the convenience of perceiving the material, a detailed list of operations performed during the incoming inspection of parts is excluded from the list. Only the most important elements that occupy the largest share are highlighted.

An expert assessment of specialists based on real data allows us to conclude that there are significant reserves for reducing the duration of processes. It is possible to reduce the duration of the incoming inspection of parts by more than two times, which, in turn, affects the rhythm of the main production, the level of utilization of equipment and workers, eliminates unproductive losses of time, and increases labour productivity.

At the same time, the quality of the incoming control does not deteriorate, the duration of the main control processes does not change, only the waiting time associated with the irrationality of interaction and the lack of automation of the processes of preparing and coordinating information is reduced.

\subsection{Research of reserves of increase of efficiency of use of working time}

Research of reserves of increase of efficiency of use of working time and to minimize and losses, holding on JSC "UZGA", directed at the reduction of the complexity of the actual products, the company's aircraft industry, which will produce a larger volume of production, while maintaining the current state of the workers and used space. These 
changes will directly affect the reduction in the cost of products, which will have a positive effect on all related indicators, such as profit and profitability, as well as increase the competitiveness of the plant and even the industry as a whole.

Data collection for the study was conducted using the method of photo- timing of the day the main workers of various specializations during 3 months. The total observation time was 50 work shifts or 24,000 minutes, the summary structure of working time costs is shown in Figure 1.

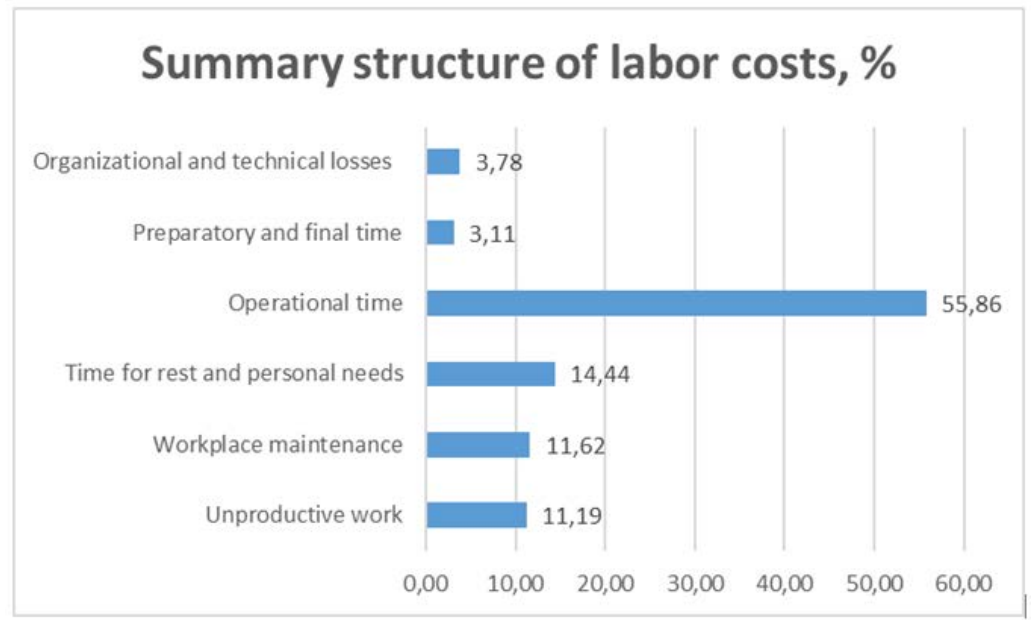

Fig. 1. Summary structure of working time costs.

The results suggest that the operational time is actually spent on production, less than $56 \%$. This indicates possible shortcomings in the organization of production and labour at the enterprise and requires consideration of the reasons for the relatively low efficiency of the use of working time.

The biggest item is the obvious waste - the time of unproductive work. This includes communication and discussion with colleagues of different issues, including a conversation with a specialist in planning and organizing the work, obtaining advice and clarification on the technology for documentation and some operations of the process.

Also, the elements of unproductive work include the correction of defects, the search and adjustment of the tool, the adjustment of equipment, and so on. A summary of the overhead categories is shown in Figure 2.

\section{Unproductive work losses structure,}

$\%$

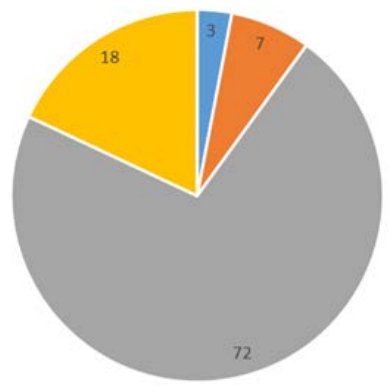

- search for the required tool

= elimination of equipment malfunction

- interaction with employees on various issues

= shutdown of the workshop for various reasons

Fig. 2. Unproductive work losses structure, $\%$. 
In addition to unproductive work, there is a large loss of time for organizational and technical reasons. They are caused by various reasons:

-presentation of finished parts or intermediate stages to technical control services;

- giving workers the wrong set of parts and materials;

-lack of tools at the workplace, for which you have to go to the tool pantry;

-filling out various documentation, such as interoperation cards, etc.

\section{Results}

In general, for each group of reasons, an optimization solution can be found that minimizes the loss of time. First of all, it is worth using passive observation time to perform parallel work on other tasks. It was noted that the waiting time of a colleague from the Quality Control Department or waiting for the glue and paint to dry is often regarded by workers as free time and are happy to spend it on personal matters not related to work.

A significant proportion of the time is spent on checks and a set of parts for defects and compliance with technological documentation. In addition, a common problem is the lack of materials in the warehouse, which can lead to a whole team of workers standing idle for several days. Here it is worth placing more responsibility on the supply and incoming control service in order to minimize the time spent by workers on reconciling items and not to do double work.

Tool preparation should be carried out at the beginning of the shift and planned by the worker at the end of the previous shift. This will allow to grab a tool before starting work and not waste time trekking to the tool store. The quality of the issued tool must be checked by warehouse workers, who are obliged to clearly check the characteristics of the tool and carry out timely repairs.

The remaining losses of working time are partly laid down in the categories of rest and personal needs, as well as in the time spent on servicing the workplace. Each of this category makes up more than $11 \%$ of the total observation time, although the standard values adopted at the enterprise for each of them, on average, are about 5\%. This demonstrates the possibility of optimization through organizational decisions.

It should be noted, that at the moment the plant is dominated by manual labour, high physical activity. In this regard, foremen and shop managers should consider automating production processes or using state-of-the-art manual tools to help workers perform their duties faster and more comfortably.

It's important to improve labour discipline at the enterprise. First of all, this will allow minimizing delays and workers during technological breaks, the time of which is very often exceeded due to lack of control.

Table 2. Measures to optimize working time.

\begin{tabular}{|c|c|c|c|c|}
\hline \multirow{2}{*}{ Labour time cost category } & \multicolumn{2}{|c|}{ Indicator value, $\%$} & \multirow{2}{*}{$\begin{array}{c}\text { Relative savings in } \\
\text { numbers of } \\
\text { personnel }\end{array}$} & \multirow{2}{*}{$\begin{array}{c}\text { Max. labour } \\
\text { productivity } \\
\text { growth, \% }\end{array}$} \\
\hline & base & planned & & \\
\hline Rest and personal needs & 14,4 & 8 & 3 & 6,8 \\
\hline Workplace maintenance & 11,6 & 6 & 2 & 5,9 \\
\hline Unproductive work & 11,2 & 6 & 2 & 5,5 \\
\hline $\begin{array}{l}\text { Organizational and technical } \\
\text { losses }\end{array}$ & 3,8 & 2 & 1 & 1,8 \\
\hline Total & & & 8 & 20,0 \\
\hline
\end{tabular}


With the help of optimization measures, theoretically, it is possible to achieve an increase in labour productivity by $20 \%$ compared to the current situation (table 2 ). This will entail a lot of positive changes, optimize costs and increase profits of the enterprise, the possibility of further development, expand products and increasing competitiveness in general.

Working time research also can be used for updating the established norms time to perform the processes and operations.

\section{Conclusion}

The peculiarity of the conditions of small-scale and unit-type production leads to an increase in the duration of production preparation processes, peculiarities in the organization of the main production, the need to ensure the flexibility of production systems, a high level of personnel training, and the complexity of rationing the labour intensity of operations. Despite the fact that the main factor in the growth of labour productivity remains the use of innovative technologies, the use of organizational factors, as shown by the study, also contains significant reserves for intensifying processes.

\section{References}

1. «Order of the Government of the Russian Federation of June 6, 2020 No. 1512-r On approval of the Consolidated Development Strategy of the Manufacturing Industry of the Russian Federation until 2024 and for the period until 2035» The official website of the Russian Government URL: http://government.ru/news/39452/

2. Rosstat recorded an increase in the dependence on raw materials of the Russian economy. The official website URL: https://www.vedomosti.ru/economics/articles/2020/02/17/823221-rosstat-zafiksirovalusilenie

3. Glezman L.V., Pytkin A.N. The competitive environment of a machine-building enterprise in the management of the production program // Proceedings of the conference "Forecasting the innovative development of the national economy in the framework of rational environmental management." 2015.S. 331-341.

4. Prilutskaya, MA, Murukina, AD, Tipner, LM, \& Kalinina, NA (2020). Diversification instruments for machine-building enterprises. IOP Conference Series: Materials Science and Engineering, 971 (5), [052012]. https://doi.org/10.1088/1757$\underline{\text { 899X/971/5/052012 }}$ 